Mesa 4

\title{
Introducción: Arte, Publicidad y Vida Cotidiana en los Espacios del Arte. Publicidad: el Arte Tapado
}

\author{
Manuel ÁlVAREZ JUNCO ${ }^{1}$ \\ Universidad Complutense de Madrid
}

«El arte es lo nunca visto»

(José Cruz Novillo)

\section{Información, propaganda y publicidad}

Lo «publicitario» se suele confundir con lo «comercial», pero dentro de lo que se «publicita o se hace público» se encuentra una variedad de piezas con cometidos que nada tienen que ver con tal denominación. Esto afecta de manera fundamental a su relación con el espectador y a la consideración de sus aspectos artísticos. La publicidad abarca lo que es meramente informativo (anuncios institucionales, bandos, avisos, señalética, packaging, etc.), lo propagandístico o difusor de ideas (campañas políticas o sociales, prevención de accidentes laborales o de tráfico, indicaciones sobre salud pública, etc.) y lo meramente comercial, destinado a obtener una difusión y venta de productos.

Estas últimas, las más numerosas y entendidas popularmente como «publicidad», incluyen sin duda también las funciones de «informar» y «aconsejar», pero su finalidad y razón de ser es la venta de algo. El hecho de su intencionalidad comercial y el que su valor sea medido por su capacidad de captar clientes las va a condicionar especialmente en su apreciación como arte, observando que establecen con el usuario una relación de empatía inversamente proporcional a la finalidad «interesada» o no de un anuncio. Cualquier campaña de información o de estricta

1 Profesor Titular de la Facultad de Bellas Artes. En el momento de celebración de las Jornadas era, además, Vicerrector de Cultura y Deporte de la Universidad Complutense de Madrid. Correo electrónico: bbaajun@art.ucm.es 
propaganda (fines sociales) será mejor considerada y más cercana que otra equivalente de publicidad (fines comerciales). Asimismo dentro de las campañas propagandísticas en sí se verán con mejores ojos las más desprendidas (tráfico, salud, género, pobreza, discapacidad, ecología, etc.), que las más interesadas (políticas o religiosas).

Dos campañas de similar calidad y «artisticidad» con finalidades distintas serán radicalmente diferentes dependiendo del factor «interés final»o «generosidad». El mismo anuncio, por muy atractivo, sutil, sensible y de excelente factura que sea, será menos apreciado si su destino es vender algo que si no lo es. Lo comercial se verá como un aprovechamiento particular y ajeno, mientras lo social será visto con una intención de ayuda colectiva y cercana.

Es paradigmático el caso de las campañas de Benetton en las que provocaba una empatía a través de imágenes que denunciaban injusticias o llamaban a la solidaridad, pero que incorporaban la banda verde con el «United Colors of Benetton», la marca de ropa de Treviso. En definitiva, estos gritos propagandísticos eran «publicitarios» vendían.

Con menor brillantez pero no una intencionalidad muy alejada de la Benetton se ofrecen ahora anuncios con un carácter ecológico o solidario, de unión ante el cáncer o lucha contra la pobreza, la discapacidad, de apoyo al mayor, etc., todo con unas marcas conductoras que muchas veces poco tienen que ver con esas causas.

Dejemos de momento esa idea de que la diferenciación de acuerdo con la expresión de su intencionalidad de algo publicitado acerca o aleja su consideración de arte, donde este se percibirá como una propuesta más desprendida, como una creación no interesada y, por ello, cualitativamente mejor.

\section{El arte y la calidad}

En esta vida, distinguimos perfectamente lo que nos da o nos regala algo deseado de aquello otro que no nos compensa o nos deja indiferentes. Qué duda cabe que siempre sabemos reconocer lo que nos agrada, nos conmueve y reconforta.

El arte es algo que permite afrontar los retos de lo humano y, por tanto, algo estimulante, beneficioso y enriquecedor. Podríamos incluso apreciarlo como aquello que sorprende al proporcionarnos lo que buscábamos y que no esperábamos recibir. Según estos valores, la «artisticidad» sería relacionable con lo que se puede denominar la «calidad», es decir, lo novedoso y superior.

El criterio cualitativo siempre es algo subjetivo y complicado de concretar y definir aunque sí lo podemos afirmar como cercano a lo sorprendente y lo privilegiado, y así a los conceptos de innovación, de creación, de acceso a algo diferenciado como positivo y cómplice. Por el contrario, se puede enfrentar el valor calidad (aquello que es distinto y mejor, términos siempre comparativos) con algo opuesto: el sometimiento, la dependencia y la sumisión a lo ajeno. La consecuencia que se 
deriva de esta premisa es que cualquier elemento que afecte a esa «generosidad» irá en detrimento de lo valorado como fiable y nos hará insensibles a su posible magia, hará disminuir nuestro interés al parecernos «interesado».

La publicidad comercial tiene una declarada (y exclusiva) misión que es la obtención de una mayor venta según el resultado buscado por el cliente que la encarga. Por ello, se puede considerar una publicidad de excelencia (de calidad) la de mejor difusión, conocimiento y éxito del producto anunciado. Esto sin embargo nos puede dar una visión absolutamente limitada e incluso falsa si la tomamos con demasiada cercanía, ya que solo la valoramos desde el estricto mandato que la motivó: un exitoso resultado comercial. No tendremos la misma opinión desde otro punto de vista mucho más importante: el resultado estético-simbólico del anuncio, es decir, lo que sorprendió satisfactoriamente y sedujo al espectador.

Esto significaría que el publicitario cometería un error buscando de entrada «vender» (en el sentido popular del término) un producto, y acertaría acogiendo al espectador, trayéndole a su lado, haciéndole cómplice y amigo, por medio de un mensaje cautivador. Este adjetivo «cautivador» significaría atraparle por medio de la calidad, lo que denominamos superior y novedoso, es decir, lo que decíamos artístico. Una conclusión de la que se derivase esta afirmación de que la calidad depende de la estética sería hallar un atajo conceptual para nuestro entendimiento de las creaciones publicitarias.

En los últimos tiempos podemos observar el hecho de una publicidad en ese sentido, ajustada a la hipótesis por la que la calidad se alía con el arte (excelencia, creación, innovación) intentando marcar una distancia con la apariencia comercial. Anuncios sorprendentes de enorme atractivo conceptual y plástico plantean contenidos abstractos plagados de simbologías potentes, dinámicas, sutiles o intensas, sugerentes, delicadas o enérgicas, pero casi sin referentes con respecto a una marca, a un producto concreto. Parece que quisieran evitar el calificativo de comercial. Esto conlleva a menudo un problema de falta de memorabilidad y de identificación con el anunciante, pero aportan la ventaja de un irresistible impacto plástico, simbólico (¿estético?). Nike, Ikea, Coca-Cola, Volkswagen, Aquarius, Adidas o Audi, por ejemplo, ofrecen increíbles realizaciones de una hermosa factura y un concepto atrevido y diferenciado donde se relaciona la marca no con sus propiedades prácticas sino con una filosofía vital.

Aquí está el dilema de no poder servir a dos señores o amar a dos mujeres a la vez. Si atienden preferentemente a sus aspectos estéticos y simbólicos, disminuyen su finalidad interesada y ganan en calidad y atracción. En el caso de reclamar su atención comercial, no serán vistos como algo estimulante y por tanto «de calidad» quedando afectada su consideración creadora, su «arte».

Esta es la apuesta actual del mundo publicitario, consciente de que un espectador seducido por el anuncio será alguien convencido por el producto, sin importarle que no exhiba las ventajas de la marca comercial pero sí identificado con una 
simbología que le hace sentir superior. Además, si es relacionable y memorable con la marca, como algunas de las producciones antes citadas, mejor.

Esta consideración afecta al arte que se encuentra inmerso en la publicidad porque desarrolla la eclosión de un mundo de creación de símbolos. Su apreciación como arte necesitará una maniobra de desentrañamiento.

\section{Maniobras de desactivación}

La presencia en espacios propios del arte de obras nacidas para la publicidad se debe a ese alargamiento que se ha producido en las últimas décadas en los lugares propios de exhibición creadora que lleva a acoger realizaciones antes no incluidas en sus listados y que ofrecen indudables aspectos, contenidos y formas propios del arte y que como tal deben ser tratados.

A principios del siglo XX, el Arte había terminado de realizar su periplo de fijación en torno a un eje maestro, a una definición, a una gran referencia identificatoria: su desprendimiento de cualquier servidumbre, sin otra finalidad sino la estrictamente estético-simbólica. Parecía, por tanto, claro que cualquier tipo de obras que llevara la característica de un encargo previo, se alejaría más y más del marchamo artístico.

Había casos señalados que se esgrimían en sentido contrario, probando que el «arte encargado» había entrado en los museos por la puerta grande. Así se explicaba la presencia de carteles de Toulouse-Lautrec, Chéret, Breadsley, Mucha, Rodchenko, Cassandre, etc. Lo que no se analizaba es que esas piezas desvelaban, distanciadas por el tiempo de su realización, los aspectos más estético-simbólicos, cuando su función práctica se había desvanecido, y podíamos apreciar el arte que contenían separándolo de la utilidad que les había motivado. Por ejemplo, un cartel de Cassandre ya no anunciaba la salida del barco Normandie rumbo a Nueva York ni otro promovía el tren de L'Etoile du Nord, sino que como nunca ahora se destacaban sus colores y formas, su plasticidad, la armonía y brillantez de su composición. Igualmente un cartel litográfico de Lautrec, un grafismo comercial o una llamada a la lucha de Rodchenko o bien una pieza de Miró solicitando ayuda para la Guerra de España, ya no realizaban su función de anuncio para pegar en un muro, sino la de «poster» para colgar en un salón.

La relación del arte con el diseño, habitual en nuestros días, tuvo sus inicios en la Bauhaus. Allí se hizo una revisión de las formas industriales, al principio seguidoras y de acuerdo a referencias plásticas mientras el mundo del arte -Klee, Kandinsky, Albers- reflexionaba sobre el «lenguaje de la plástica», su morfología y sintaxis: las reglas de uso de los símbolos o, en definitiva, los mecanismos de la Comunicación Visual. Su consecuencia sería la inmersión en la semiótica, la apreciación del significado como motor de cada pieza, el rechazo total de la estética en el sentido plástico convencional y la afirmación de la (no) estética del signo. 
Esas secuencias iniciadas hace una centuria, la del arte marcando su desapego del encargo a la vez que estudiaba el lenguaje comunicador y la del diseño descubriendo el símbolo, han derivado en la curiosa relación y entrecruzamiento de piezas de ambos ámbitos, a veces de la manera confusa que observamos en las últimas décadas.

Dentro del concepto de «calidad» intervienen factores con una enorme carga simbólica. Lo que llamamos de manera genérica la estética publicitaria tiene hoy un sentido no esencialmente de belleza plástica, de apreciación de formas y colores, y dependiendo del «target» se dirige a la sutileza, la fuerza, la poesía, la dinámica, el sarcasmo, la elegancia, el ritmo, la aventura, etc. presentando toda una batería de elementos estrictamente simbólicos dirigidos a la atracción y el recuerdo placentero de sus destinatarios. La belleza en el sentido clásico tampoco la utiliza el arte actualmente y una publicidad con criterios estéticos nos conduce a una ineludible definición de sus aspectos simbólicos. Hoy un anuncio inteligente busca la identificación del receptor con algo potente y simbólicamente «superior», donde se centraría el valor cualitativo. Esto, tan aparentemente paradójico ya que implica despojar a lo publicitario de su inicial razón de ser, es sorprendentemente lo que pretende el propio anunciante en el fondo: involucrar al «target», hacer que haga suyo el producto, que lo incorpore cualitativamente como bueno para él.

Por eso mismo, para «ver» el arte contenido dentro de la publicidad, este debe ser «destapado», para lo que se precisa de una maniobra de desactivación de su carácter comercial. El mismo hecho de la inclusión de determinadas piezas en los dominios del arte conlleva esa desactivación, la cual se produce automáticamente al entrar en los lugares artísticos, obteniendo la distancia adecuada de su medio y su consiguiente consideración por los valores estético-simbólicos propios de una creación más.

\section{La Publicidad, el Arte y el Artista}

La publicidad exige un trabajo controlado, vigilado por un equipo rector, una labor colectiva comandada por el briefing. El arte exige prácticamente lo contrario, es decir, la libertad de ataduras y el desapego de cualquier objetividad, la intervención de la intuición. Una extrema racionalidad en la detección del problema y en la metodología que se va desarrollar es algo consustancial con la publicidad. Con esa previa objetividad, es decir, con el camino bien trazado y definido su final, con sus márgenes señalizados y su meta al fondo, es cuando el artista puede y debe intervenir en una producción publicitaria.

El arte y la publicidad poseen un aspecto común como es el proceso de creación, pero la publicidad es, como el diseño, absolutamente siempre una adecuación de medios afines, donde se establece un claro proceso intelectivo con unas funcionalidades establecidas de antemano; y el arte, aunque su configuración final pueda 
expresar algunas adecuaciones funcionales, siempre es libre de partida. La intuición y la expresión colectiva, conceptos propios del arte, se encuentran irremediablemente en la publicidad, al igual que la racionalidad, la planificación, el oficio y la corrección metodológica, propios de la publicidad, están también de arte.

En el proceso de creación, el conocimiento concreto y la información precisa del briefing que debe resolver el publicitario le llevará al entendimiento de lo que busca, de lo que debe hallar, de la meta a conseguir, del final de su periplo; pero esa comprensión, ineludible en la elaboración de un anuncio, suele ser un elemento ajeno absolutamente al mundo del arte. Esa premisa propia de la publicidad es la que «carga» la acción que debe ser realizada por el director artístico. A partir de ahí, y sorprendentemente solo después de esto, se reclama la presencia de un artista.

$\mathrm{El}$ artista es el aventurero que se adentra en un mundo blanco y sin aristas donde afronta el arriesgado compromiso de lograr la definición de su contorno y sus detalles para ofrecer su complejidad de forma sencilla y conseguir mostrar el mundo como nunca se ha visto, dar a conocer de manera nueva lo que se creía ya sabido.

Considerar arte la publicidad debe ser matizado, ya que antes debemos «desactivarla»; pero observar en ella la necesaria presencia del Artista es acertar en la necesaria aportación cualitativa, es decir, la incorporación de lo sorprendente, nuevo y superior. La inclusión de la publicidad en los espacios museísticos no obliga en absoluto a revisar el concepto mismo de Arte porque nos conduce ineludiblemente a una inequívoca y rotunda afirmación del Artista. 